\title{
Tributary glacier surges: an exceptional concentration at Panmah Glacier, Karakoram Himalaya
}

\author{
Kenneth HEWITT \\ Cold Regions Research Centre, Wilfrid Laurier University, 100 University Avenue, Waterloo, Ontario N2L 3C5, Canada \\ E-mail: khewitt@wlu.ca
}

\begin{abstract}
Four tributaries of Panmah Glacier have surged in less than a decade, three in quick succession between 2001 and 2005. Since 1985, 13 surges have been recorded in the Karakoram Himalaya, more than in any comparable period since the 1850s. Ten were tributary surges. In these ten a full run-out of surge ice is prevented, but extended post-surge episodes affect the tributary and main glacier. The sudden concentration of events at Panmah Glacier is without precedent and at odds with known surge intervals for the glaciers. Interpretations must consider the response of thermally complex glaciers, at exceptionally high altitudes and of high relief, to changes in a distinctive regional climate. It is suggested that high-altitude warming affecting snow and glacier thermal regimes, or bringing intense, short-term melting episodes, may be more significant than mass-balance change.
\end{abstract}

\section{INTRODUCTION}

There are reports of 34 surges in the Karakoram since the 1860s involving 23 glaciers (Hewitt, 1969, 1998). Twelve of these are tributaries, detached from or joined to main glaciers that are not known to surge. Many surges, especially of the less accessible tributaries, may have gone undetected. All but one of the main glaciers reach inhabited areas or terminate near important trails, making reports of their activity more likely.

Since 1985, more surges have been recorded than in any comparable period in records since the 1850s (Mason, 1930; Hewitt, 1969). Of thirteen events, ten have been tributary glacier surges; improved observation may be a factor. However, equivalent numbers are not evident in satellite imagery before 1985, suggesting a real increase in events since then. Moreover, four independent tributaries of Panmah Glacier have surged in the past decade, three of them in quick succession between 2001 and 2005 (Fig. 1). Landsat imagery shows that two tributaries of the adjacent Sarpo Laggo Glacier, and another in an unnamed basin nearby, surged some time after 1995 (Table 1). This concentration of events is unprecedented.

The perennial snow and ice cover of the Greater Karakoram Range and adjacent Hindu Raj is about $18500 \mathrm{~km}^{2}$ (von Wissmann and Flohn, 1959). It is dominated by large glaciers with no record of surges. The 12 largest basins comprise almost half the cover. The glaciers are at globally extreme elevations and have exceptional elevation ranges. Generally, they differ in elevation and climate regime from most of the glaciers used to track contemporary glacier change (Oerlemans, 2001). Recent events raise two broad issues: the nature of surging tributaries and reasons for this sudden concentration of them. These issues are addressed after describing the surges in the Panmah Glacier system.

\section{RECENT PANMAH GLACIER TRIBUTARY SURGES}

Panmah Glacier is the sixth largest glacier in the region and is composed of two main branches joining $7 \mathrm{~km}$ above the terminus. All four recent surges are in west- or southflowing, east-bank tributaries of the Nobande Sobande
Glacier branch (Fig. 1). Before any surges were reported, three of these tributaries were classified as 'suspected' surging glaciers by Kotlyakov (1997, plate 406). The four surges affect Chiring, Maedan, Shingchukpi and Drenmang Glaciers. The first three had detached and retreated from the main glacier since the 1930s, but all four now contribute ice to it.

The 1995 Chiring Glacier surge was described by Hewitt (1998). By the summer of 2005, marked thickening was observed in its accumulation zone. The entire ablation zone had thinned to $10-50 \mathrm{~m}$ below the 1996 profile. It was no longer heavily crevassed but remained active throughout. Tributaries sheared off in the surge have now adjusted to enter at the present ice level.

Maedan Glacier surged some time after 2002, causing major thickening and break-up of its lower $8 \mathrm{~km}$ (Fig. 2). Along the side-walls were masses of dirty ice, in places more than $100 \mathrm{~m}$ above pre- and post-surge levels, evidence of a 'mid-glacier zone' of the surge, with 'compressive followed by extensive flow' (Murray and others, 1998, p. 271). When observed in July 2005, the surge was over but the lower Maedan Glacier surface remained a mass of seracs. A smoother lobe of its ice, $\sim 3 \mathrm{~km}^{2}$ in area, had entered the main Nobande Sobande Glacier and formed a series of concentric ridges, with the highest at the outer rim, reflecting a zone of compression continuing after the surge. Opposite the junction, Chiring Glacier was compressed to a narrow, heavily crevassed thread. The lobe of the 1995 Chiring Glacier surge ice in the main valley was distorted by Maedan Glacier, but its outer rim was still a well-defined, steep-sided ridge of ice $\sim 40-60 \mathrm{~m}$ high.

The Maedan Glacier surge was preceded by a steady advance. In September 1992 its terminus was $\sim 3 \mathrm{~km}$ from Chiring Glacier, but had advanced $1.5 \mathrm{~km}$ by 1996 . It reached Chiring Glacier in 2000, 2 years before the surge.

Shingchukpi Glacier lies parallel to Maedan Glacier, its basin having a similar aspect and morphology. In 1996 the terminus was $\sim 2.5 \mathrm{~km}$ from the main glacier. Like Maedan Glacier, it advanced steadily almost $2 \mathrm{~km}$ before the surge, which began in the fall or winter of 2004/05 and was still in progress in July 2005 (Fig. 3). Again, sections of dirty marginal ice were stranded tens of metres up the valley 


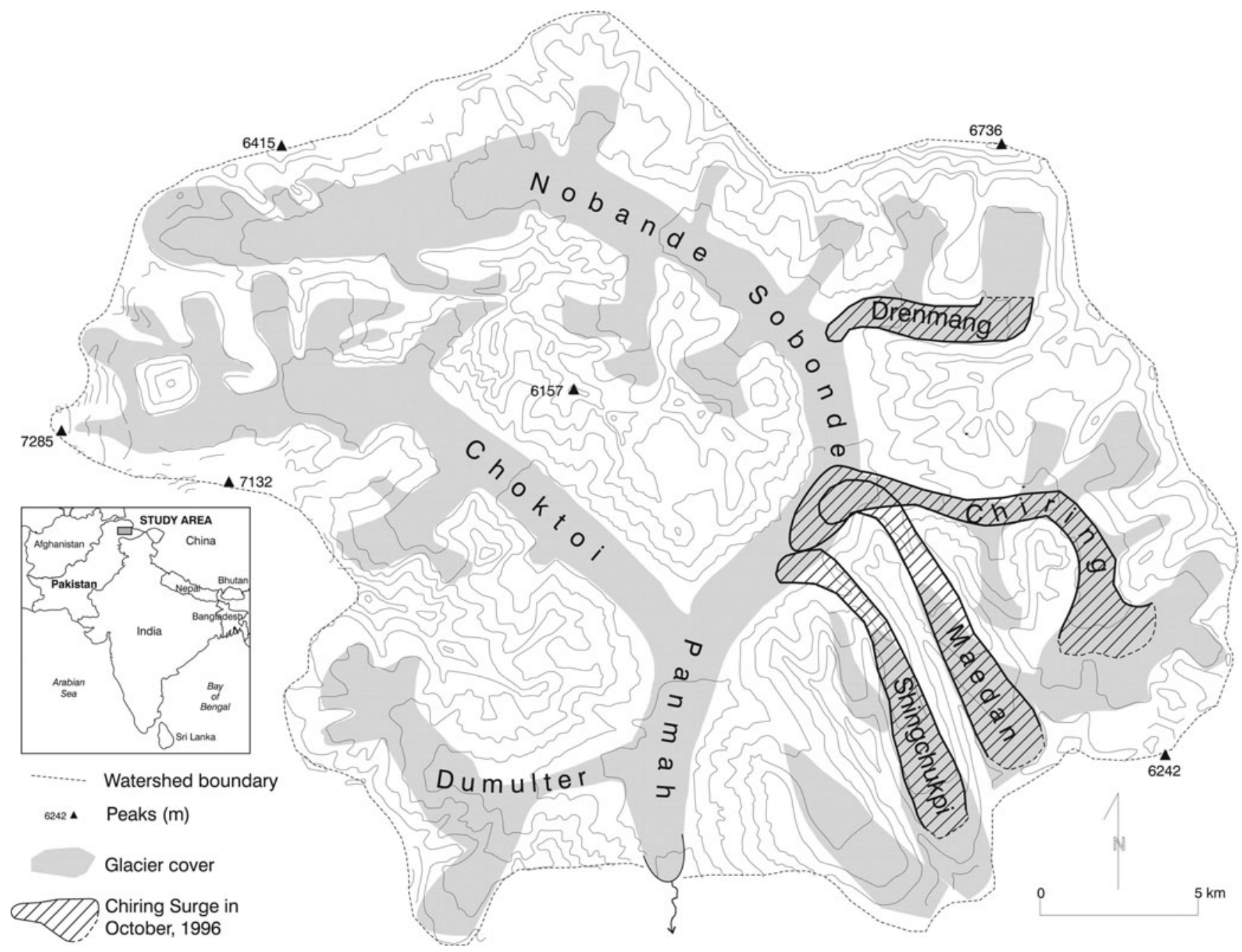

Fig. 1. Map of Panmah Glacier showing four recent surges. The heads of ice streams are shown schematically to reflect how most of the basin above $5000 \mathrm{~m}$ consists of rock walls, seasonally or perennially snow-covered, subject to all-season avalanching, and with countless small, steep ice masses that contribute to the trunk streams through ice avalanches.

walls. The seracs of Shingchukpi Glacier remained distinct from Nobande Sobande Glacier ice, which had been pushed into a series of relatively smooth concentric ridges, broken systematically by transverse crevasses. The three innermost ridges had cupola-like crests, curved bridges of highly stressed ice that shattered at a slight touch. Masses of ice breccia occurred along the crests or beneath the cupolas (Fig. 4).

The Drenmang Glacier surge probably began in the fall or winter 2004/05, coming from the east branch, the larger of Drenmang Glacier's two main sources. When visited in 1996, and on Landsat imagery to 2001, ice from the shorter western branch occupied more than half the combined area beyond their junction. By the summer of 2005 this relationship was reversed. There were steep ice cliffs along both flanks of the eastern branch, and broken masses of dirty ice were overriding lateral moraines that had been ice-free for some decades (Fig. 5). The central areas were more crevassed than in 1996, but not as severely broken as on Shingchukpi or Maedan Glacier, perhaps because the surge was in an early stage.

\section{Features of tributary surges}

Each of the Panmah tributary glacier surges involved the usual sudden acceleration, severe break-up of the glacier surface, rapid thickening and terminus advance. In the accumulation basins, surface collapse marked the upper limits of the surges and new or expanded crevasses. The highest of the disturbances were at 5400 ma.s.l. for Chiring Glacier, $5200 \mathrm{~m}$ for Maedan and Shingchukpi Glaciers and, to July 2005, $5100 \mathrm{~m}$ for Drenmang Glacier. These limits are $\sim 1200$ to $1600 \mathrm{~m}$ lower than the watershed maxima, so the surge events were confined to about the $1000 \mathrm{~m}$ range in elevation. The impeded run-out suggests the elevation ranges and 'surge lengths' are different from main glacier surges. Moreover, a distinctive three-fold partitioning of surge-transferred ice occurred between the tributary and main glaciers and post-surge stagnant ice.

As described for Shingchukpi Glacier, there are large, immediate impacts on the main glacier, but half or more of the surge ice remained in the lower tributary valleys to enter the main glacier in a post-surge, or relaxation, phase. As with all observed Karakoram examples, actual surges were short-lived, lasting a few months, unlike those reported from Svalbard, for example, which last several years (Dowdeswell and others, 1991). However, at Chiring Glacier, 'quiescent' phase conditions were not resumed in the ablation zone for at least 6 years. Until then, flow rates and crevassing remained greater than before the surges or at present. Likewise, 2-3 years after the Maedan Glacier surge, 


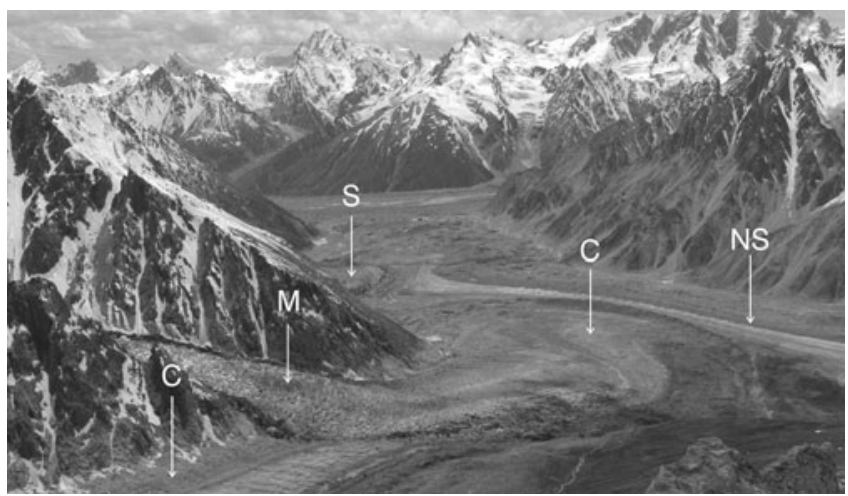

Fig. 2. Overview of Maedan (M) surge in July 2005 where it enters the Chiring (C) and Nobande Sobande (NS). The lobe Chiring (C) surge ice is also seen and the conspicuous pressure ridge at its rim. The outer part of the Shingchukpi (S) surge is visible in the middle distance.

one-third of the surge ice, estimated relative to the pre-surge surface, remained in the tributary ice stream. An even larger fraction was observed in Shingchukpi Glacier after the surge front had passed its full length. Thus, in July 2005, the four events represent different surge and post-surge phases from Chiring Glacier, essentially returned to quiescent or 'normal' behaviour, to Drenmang Glacier, then in mid-surge. Similarly extended periods of post-surge adjustments were observed by the author in the years following the tributary surges of Pumarikish Glacier into Hispar Glacier in 1989 (Wake and Searle, 1993), and Liligo Glacier into Baltoro Glacier in the mid-1990s (Pecci and Smiraglia, 2000). This extends and complicates the notion of surge episodes, or their impact in mountain valleys, suggesting a need to define a condition intermediate between surging and 'normal' flow behaviour.

Major, post-surge adjustments of the main glacier also continue for some years. They include progressive distortions of pre-existing surface features, including the looped and 'teardrop' forms widely associated with surging glaciers

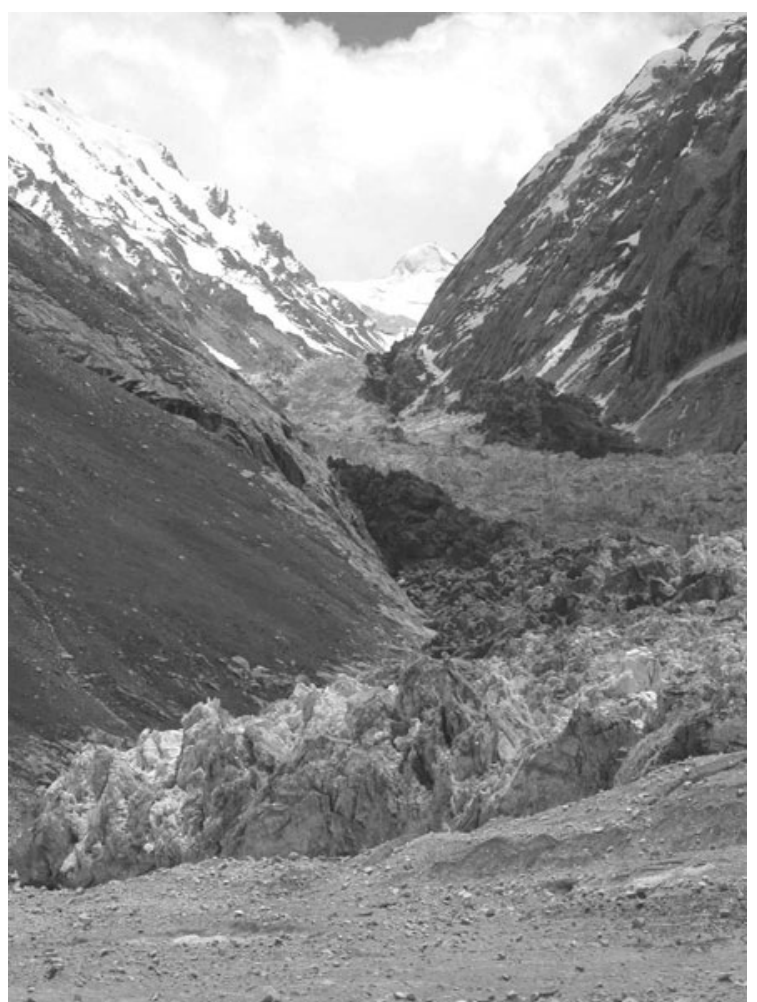

Fig. 3. Shingchukpi Glacier surge, July 2005. The surface consists almost wholly of seracs, and dirty ice is thrust up irregularly at margins. View is from Nobande Sobande ice in foreground.

(Lawson, 1996). In the Panmah Glacier system, developments were complicated by interactions among the several surges occurring in rapid succession (Fig. 6). However, the boundaries of the ice from each surge were still well defined years after the surges.

Only one case is known of a surging tributary directly causing advance of the main glacier: the Lokpar Glacier surge, which occurred sometime between 1989 and 1993. It caused a rapid advance of the main Aling Glacier terminus of $\sim 1.5 \mathrm{~km}$ (Hewitt, 1998), and a further $2 \mathrm{~km}$ of

Table 1. Surging tributaries: dimensions of Panmah and other glaciers with tributaries that recently surged in the central Karakoram

\begin{tabular}{|c|c|c|c|c|c|c|c|}
\hline \multirow[t]{3}{*}{ Glacier } & \multirow[t]{3}{*}{ Location } & \multirow{3}{*}{$\begin{array}{l}\text { Area } \\
\mathrm{km}^{2}\end{array}$} & \multirow{3}{*}{$\begin{array}{c}\text { Length } \\
\text { km }\end{array}$} & \multicolumn{3}{|c|}{ Elevations/relief } & \multirow[t]{3}{*}{ Aspect } \\
\hline & & & & Highest & Snout & Range & \\
\hline & & & & $\mathrm{m}$ & $\mathrm{m}$ & $\mathrm{m}$ & \\
\hline Panmah & $35^{\circ} 57^{\prime} \mathrm{N}, 75^{\circ} 55^{\prime} \mathrm{E}$ & 720 & 44.0 & 7150 & 3350 & 3800 & Southerly \\
\hline Drenmang & $36^{\circ} 00^{\prime} \mathrm{N}, 76^{\circ} 05^{\prime} \mathrm{E}$ & 56 & 9.3 & 6740 & 4420 & 2320 & Southwesterly \\
\hline Chiring & $35^{\circ} 52^{\prime} \mathrm{N}, 76^{\circ} 09^{\prime} \mathrm{E}$ & $168(136)^{*}$ & 15.5 & 6540 & 4260 & 1940 & Northwesterly \\
\hline Maedan & $35^{\circ} 50^{\prime} \mathrm{N}, 76^{\circ} 05^{\prime} \mathrm{E}$ & 32 & 9.5 & 6540 & 4340 & 1800 & Northwesterly \\
\hline Shingchukpi ${ }^{\S}$ & $35^{\circ} 48^{\prime} \mathrm{N}, 76^{\circ} 00^{\prime} \mathrm{E}$ & 36 & 11.0 & 6700 & 4300 & 2400 & Northwesterly \\
\hline Sarpo Laggo & $35^{\circ} 54^{\prime} \mathrm{N}, 76^{\circ} 17^{\prime} \mathrm{E}$ & 359 & 29.0 & 7370 & 4070 & 3300 & Northeasterly \\
\hline Moni & $35^{\circ} 50^{\prime} \mathrm{N}, 76^{\circ} 18^{\prime} \mathrm{E}$ & 62 & 10.2 & 7780 & 4600 & 3180 & Northwesterly \\
\hline 'Unnamed' & $35^{\circ} 58^{\prime} \mathrm{N}, 76^{\circ} 18^{\prime} \mathrm{E}$ & 22 & 8.5 & 6505 & 4320 & 2180 & North-northeasterly \\
\hline 'Unnamed' & $36^{\circ} 09^{\prime} \mathrm{N}, 76^{\circ} 11^{\prime} \mathrm{E}$ & 122 & 17.8 & 6560 & 4140 & 2320 & Northerly \\
\hline 'Unnamed' & $36^{\circ} 11^{\prime} \mathrm{N}, 76^{\circ} 09^{\prime} \mathrm{E}$ & 39 & 12.3 & 6510 & 4450 & 1860 & Northeasterly \\
\hline
\end{tabular}

\footnotetext{
*Lengths prior to surges and, for Drenmang, to junction with main glacier.

†The latest Drenmang Glacier surge is from the east branch of the glacier.

*Area in parentheses is the source basin for the surge, that is, minus the 'Maedan' tributary.

${ }^{\S}$ Name adopted from the summer pasture, immediately south of the glacier.
} 


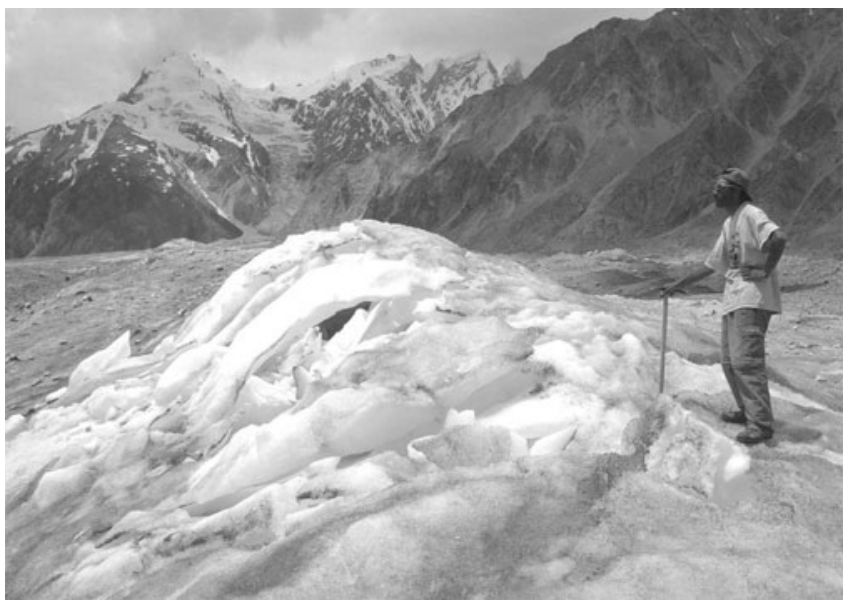

Fig. 4. Ice ridge on Nobande Sobande Glacier, $100 \mathrm{~m}$ from contact with the Shingchukpi Glacier surge ice (to left of photograph). Cupola-like bridges are shown and ice breccia beneath.

post-surge advance when observed in 2001. However, this tributary entered within $1 \mathrm{~km}$ of the snout, and the main glacier did not surge. Indeed, a reverse slope of over $100 \mathrm{~m}$ developed between the surge-elevated terminal ice and trunk stream, which has continued thinning as in previous decades.

The Panmah Glacier surges deposited large volumes of stagnant ice along tributary margins and their lateral moraines. These marked the exceptional heights reached in each surge but were subsequently sheared off, as described below. They differ from reports for main trunk surges where post-surge stagnant ice is found in lower tongue and terminus areas (Benn and Evans, 1998). For example, this was observed after the Karakoram surges of Karambar Glacier in 1993 and Bualtar Glacier in 1986, while negligible amounts of ice were stranded along their lateral margins (Hewitt, 1998). In the Panmah Glacier system, some millions of cubic metres of ice, super-elevated during the surge, were left along tributary margins, having a significant influence on moraine development and ice budget (Fig. 7). Conversely the outer lobes remain active parts of the main glacier.

The stagnant ice involved a phenomenon widely reported during surges: a well-defined line of shear or 'fault' near the ice edge or between active ice and stagnant ice, or moraine, at the glacier margin. In fact, an ice-edge line of shear is almost universal in the ablation zones of Karakoram glaciers, but undergoes exceptional development during major thickening and surges. In the rising phase of the latter, the 'fault' extends upwards and outwards and commonly projects to a vertical or overhanging ice cliff. However, following the Chiring Glacier surge the line of shear was reestablished stepwise within the ice, as the active ice stream thinned and contracted. Successive bands of dead ice recorded the changes (Fig. 2, centre foreground).

These surges did not reach the Panmah Glacier terminus, but, between 1996 and 2005, Nobande Sobande Glacier thickened for several kilometres below Shingchukpi Glacier, and reactivated ice around the junction with Choktoi Glacier. The main terminus continues to thin and stagnate, as it has since the 1930s, but in time the surges may lead to a delayed advance.

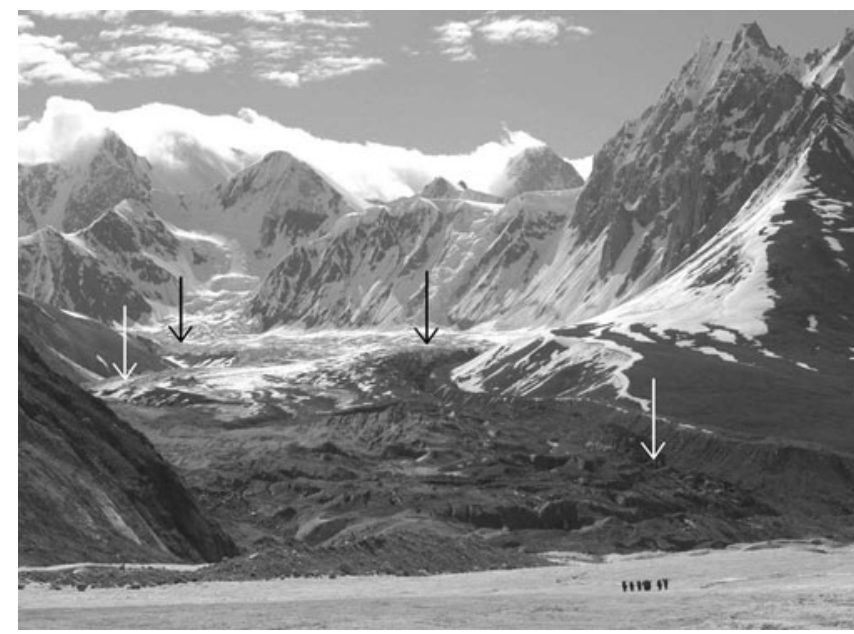

Fig. 5. Drenmang in July 2005, looking up the left-flank surging tributary from Nobande Sobande. Arrows identify surge-generated disturbances.

In general, Karakoram surging tributaries are steeper than most reported elsewhere. The mean elevation range for the whole set is $2620 \mathrm{~m}$, and the average length $11 \mathrm{~km}$, compared to $2156 \mathrm{~m}$ and $10.9 \mathrm{~km}$ for the five known Panmah surging tributaries, and $3910 \mathrm{~m}$ and $12.2 \mathrm{~km}$, respectively, for all Karakoram surging glaciers. The $20 \mathrm{~km}$ long Hassanabad Glacier, and $16.5 \mathrm{~km}$ Minapin Glacier in Hunza, evidently have the greatest elevation ranges for mountain surging glaciers: 5570 and $5400 \mathrm{~m}$, respectively, to the lower limit of their last surges (Hewitt, 1998). The $41 \mathrm{~km}$ long Khurdopin Glacier is the tenth longest glacier in the region and the longest known to surge. All the others are less than $21 \mathrm{~km}$ long, while 35 not known to surge are longer than this. These data seem to differ from key findings in the Alaska-Yukon Ranges, North America, (Clarke, 1991) and Svalbard (Jiskoot and others, 2000), where length is positively correlated with likelihood of surging. However, the Karakoram lacks such detailed inventories for comparable statistical analysis, and reports from those regions do not suggest equivalent numbers or significance of surging tributaries.

\section{INTERPRETING THE EVENTS}

Surges are generally isolated developments involving single glaciers (Sharp, 1988; Murray and others, 1998). The Karakoram record to 2000 was of widely scattered events, each seemingly unrelated to what was happening at that time elsewhere in the region, in adjacent basins or in other glaciers known to surge (Hewitt, 1998). Models explain surging in terms of internal, mainly thermal and hydrological, developments affecting the base of the glacier, possibly involving soft basal sediments (Kamb, 1987; Clarke and Blake, 1991; Fowler and others, 2001).

Nevertheless, response to climate change seems the only explanation for events at Panmah Glacier. Unlike the Susitna Glacier tributaries in Alaska (Clarke, 1991), these surges are not linked. Initially, three of the glaciers were not connected to the main glacier. Their known surge intervals do not support a mere coincidence. Historical evidence shows Maedan Glacier surged sometime between 1856 and 1861, and Chiring Glacier in 1886-87, implying recurrence intervals of roughly 155 and 120 years respectively if the 
a

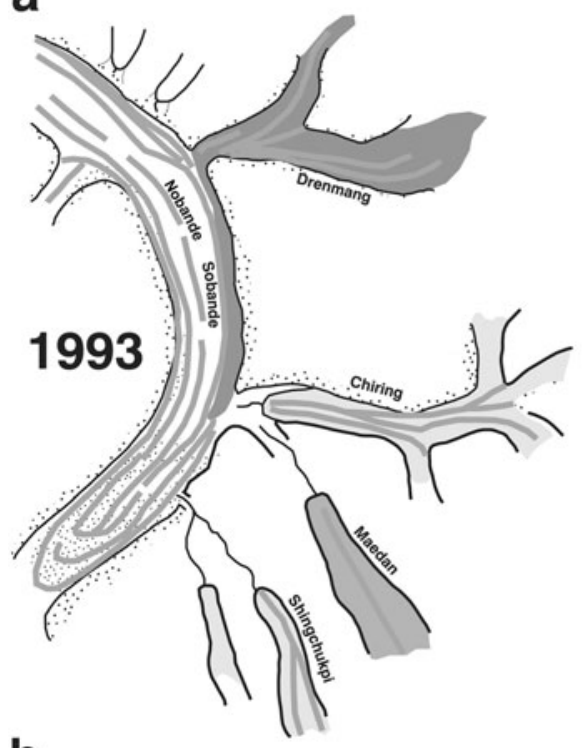

b

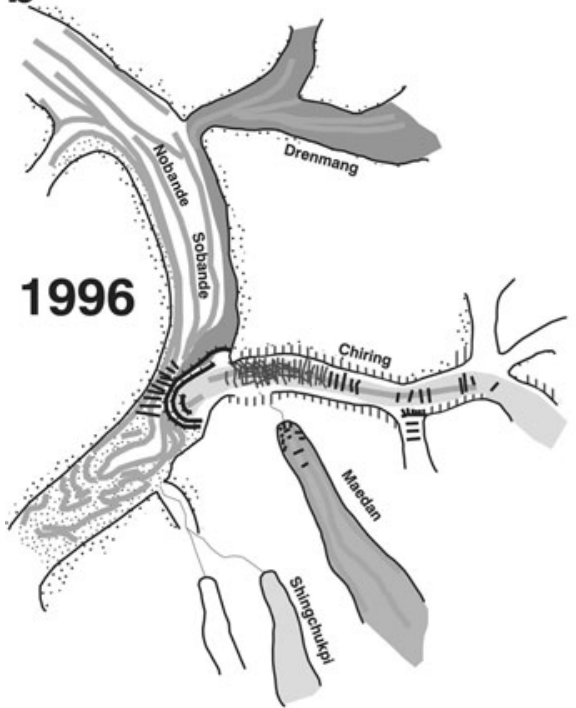

Ice streams

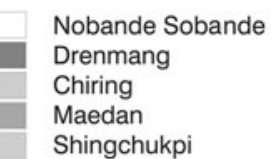

Ice margins

$\checkmark$ Active ice edge

Neoglacial moraines and kame terraces

Ice surface

$\triangle$ Supraglacial debris and moraines

Surge features and structures

Hin Crevasses

¿II Serac areas

( Pressure ridges

.... Sheared off, stranded surge ice

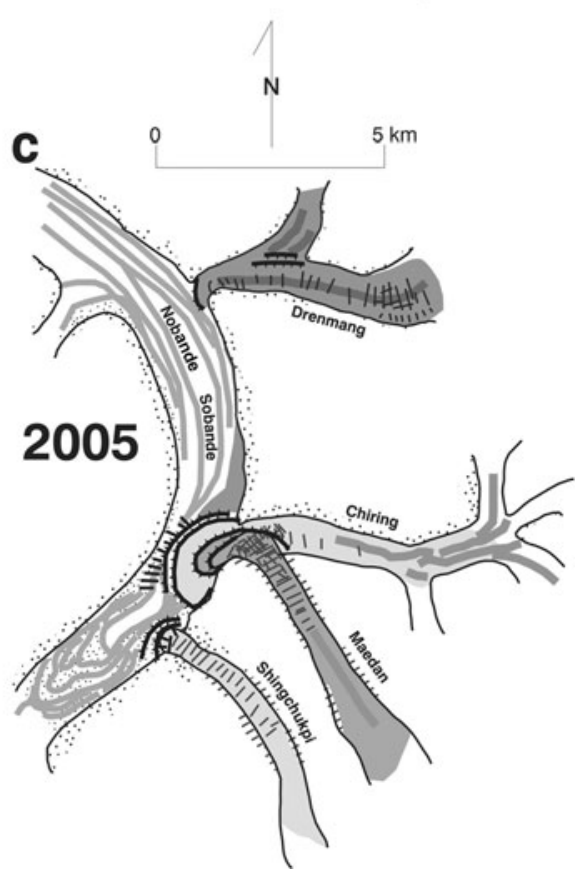

Fig. 6. Panmah Glacier surface changes associated with surges: (a) 1993, prior to Chiring surge; ice of 1977-8 Drenmang surge was just passing the mouth of Chiring indicating an average annual movement of about $500 \mathrm{~m}$; (b) 1996, conditions following the 1994-5 Chiring surge; (c) 2005, showing complex interactions of older Drenmang and Chiring surges with ongoing Maedan and Shingchukpi events. The new Drenmang surge has barely affected the main glacier.

recent surges are taken as 'regular'. Drenmang Glacier surged in 1930-31 and 1977-78, suggesting a recurrence interval of almost 50 years. Of course, the interval from 1978 to 2005 is barely half of that. Since surges appear to come from Drenmang's east and west branches alternately, their surge intervals could be different or, since they have very similar characteristics, may have been of the order of 100 years each until affected by recent conditions. Drenmang Glacier surges could be from the east and west branches at roughly 100 year intervals. No past surges of Shingchukpi Glacier are recorded, but local shepherds had identified it as a surging glacier.*
Compared with the mid- and high-latitude surging glaciers that have led theoretical discussions and modelling, investigations of Karakoram examples provide limited data. However, conditions that distinguish the region from other Himalayan and inner Asian ranges that lack surging glaciers help to bracket the interpretive issues (Fig. 8). The areaaltitude distribution of the glaciers is exceptional. All originate over $6500 \mathrm{ma}$ a.s.l.; nine over $7000 \mathrm{~m}$ a.s.I. More important for glacier mass balance and climate response, about $80 \%$ of total ice area lies between 4000 and $6000 \mathrm{~m}$, comprising most of the accumulation and ablation zones, and all of the surging tributaries.

*In 2005 a local guide referred to Shingchukpi Glacier as a 'woman' glacier, and it turned out that the guides regard all surging glaciers as female, rushing down in search of mates! The shepherds also identified several others as 'maidens', including Aling Glacier, which surged in the late 1990s, and some not previously known to surge - a promising source of information from the anthropology of glaciers. This is interesting in relation to Maedan Glacier, whose name first appears in reports of the 1929 Italian expedition (Spoleto and others, 1936, p. 222). Maedan means a plain, usually meadows, which do occur along Aling and Drenmang Glaciers but not beside Maedan Glacier. It suggests a misunderstanding or mistranslation by expedition interpreters. Most likely, local people told them it was a 'maiden' glacier. Traditional knowledge in the region identifies glaciers by gender. Combinations of 'male' and 'female' ice are used to 'seed' glaciers for water supply. 


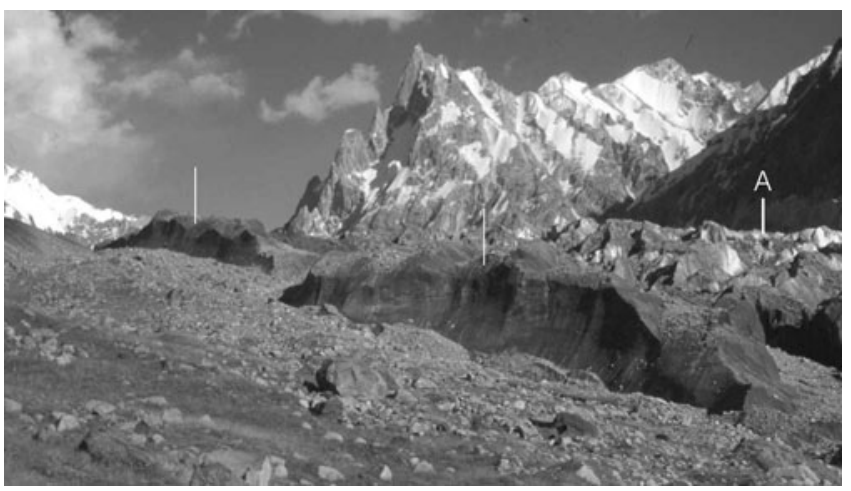

Fig. 7. Stagnant surge ice (arrows) along the post-surge Chiring margins, 1996. The heavily crevassed active ice (A) is $30 \mathrm{~m}$ below surge height but $50 \mathrm{~m}$ thicker than in 2005 when several other bands of dead ice were present below that shown here (cf. Fig. 2 and Hewitt, 1998).

There is a five- to ten-fold increase in precipitation from glacier termini $\sim 2500 \mathrm{~m}$ a.s.l. to accumulation zones above $4800 \mathrm{~m}$ a.s.l. (Hewitt, unpublished information). Maximum precipitation occurs between 5000 and $6000 \mathrm{~m}$ (Hewitt and others, 1993), i.e. 2000-3000 m higher than generally reported from the tropics (Barry, 1992, p.234). Most glaciers, and all those known to surge, are nourished mainly or wholly by avalanched snow. High-altitude snowfall, or the relative proportions of summer vs winter, can change the scale, pattern and qualities of avalanches. Mass balance could be altered in this way, and ice temperatures as well as firn temperatures and debris characteristics.

Three different climatic regimes affect the region. A 'subMediterranean', westerly circulation and cyclonic storms dominate the winter, accounting for two-thirds of highaltitude snowfall (Hewitt and others, 1989). One-third derives from summer snowfall and the Indian Ocean, mainly due to monsoon incursions (Wake, 1989). Continental anticyclones over inner Asia affect the behaviour of the other two systems and the incidence of clear weather, critical for ablation. Mass balance is intermediate between the 'summer accumulation' types of the Greater Himalaya, and winter accumulation farther west (Ageta and Fujita, 1996). Glacier climate is affected by changes in the relative strength, character and seasonality of these systems.

\section{High-altitude climate and thermal change}

There is growing evidence elsewhere that climate can influence surge incidence and event triggers. It may occur in three ways: through mass-balance change; episodes of exceptional ablation and free water ponding; or ice thermal change. Surge intervals have been shown to reflect the net rate of accumulation over intervening periods at Variegated Glacier, Alaska, and at Medvezhiy Glacier, $450 \mathrm{~km}$ northwest of Panmah Glacier (Eisen and others, 2001). Climatestation records in and around the Karakoram show statistically significant increases in winter and summer precipitation since 1961 (Archer and Fowler, 2004). They also indicate winter warming, but declining summer temperatures and temperature ranges, attributed to greater summer cloudiness and storms (Archer and Fowler, 2004). The changes suggest conditions favouring positive mass balance.

However, a huge loss of ice mass and glacier recessions were observed in almost all Karakoram glaciers for most of the 20th century until the mid-1990s. Since then there has been thickening and advances in many non-surging glaciers, but confined to the highest watersheds of the central Karakoram (Hewitt, 2005). Glaciers in the rest of the region continue to decline, including in most valleys where the climate stations are located. Also, the expansions occurred suddenly and irregularly while the climate data suggest long-term, relatively small and gradual trends, but large, short-term fluctuations.

The absence of comparative data from high altitudes makes it difficult to extrapolate changes observed at weather stations to the glaciers. Most stations are located well below $3000 \mathrm{~m}$. Moreover, mass-balance change alone seems unlikely to cause the sudden convergence of surges in glaciers formerly out-of-phase by decades. Rather, this suggests some critical threshold(s) being reached. Paterson's (1994, p. 337) observation seems pertinent here, that 'Only in temperate glaciers is the effect of a climate change restricted to a change in mass balance...' Changes in ice thermal regimes, or meltwater availability, can also induce accelerated changes in glacier behaviour and extent. All four classes of thermal regime recognized by Paterson are present in the Karakoram, sometimes in the same glacier, i.e. 'warm' ice throughout or sub-zero, 'cold' ice throughout, with the melting point reached only at the base, or only in surface layers. Measurements are few, but show variations dependent on elevation and orientation (Batura Glacier Investigation Group, 1979). Thermal shifts would most probably occur in a vertical sense, supporting the possibility of threshold changes at critical elevations.

If cold ice is warmed, flow rates may increase. The transition from frozen to wet bed conditions can dramatically affect movement by sliding, whether directly or through softening of subglacial till. It is not clear what the climatestation evidence of summer cooling means for high-altitude snow and ice temperatures. Summer precipitation at the arid valley-floor climate stations is liquid, and evaporative cooling occurs during and after rainfall, although katabatic winds as well as cloud cover tend to buffer them from intense nocturnal cooling. Conversely, accumulation zone snowfall occurs almost wholly within the cloud layer and reflects its temperature, suggesting that increased summer snowfall would increase firn temperatures. However, periods of clear weather in summer are associated with intense daytime warming, and melting of firn as high as $6000 \mathrm{~m}$ to depths of tens of centimetres. This does alternate with nocturnal freezing. Radiative cooling refreezes firn from the surface downwards, while a second freezing front develops at depth where percolating meltwater is deposited as ice lenses and layers in sub-zero firn. The latter tend to insulate firn at depth from superficial temperature changes and further moisture percolation, but with net warming from release of latent heat. Without monitoring, the situation is too complex to say what climate changes would mean in terms of the net effect on firn temperatures. Meanwhile, there are no studies of thermal conditions in the allimportant, all-season avalanche cascade that nourishes most glaciers and links a wide range of elevations; hence, no basis to say how climate change would affect it. However, winter warming and increased summer snowfall make it more likely that sub-zero ice moving out of the accumulation zones is being warmed.

Ice thermal changes are rarely invoked even for centurylong variations, since ice at depth has been found mainly to 


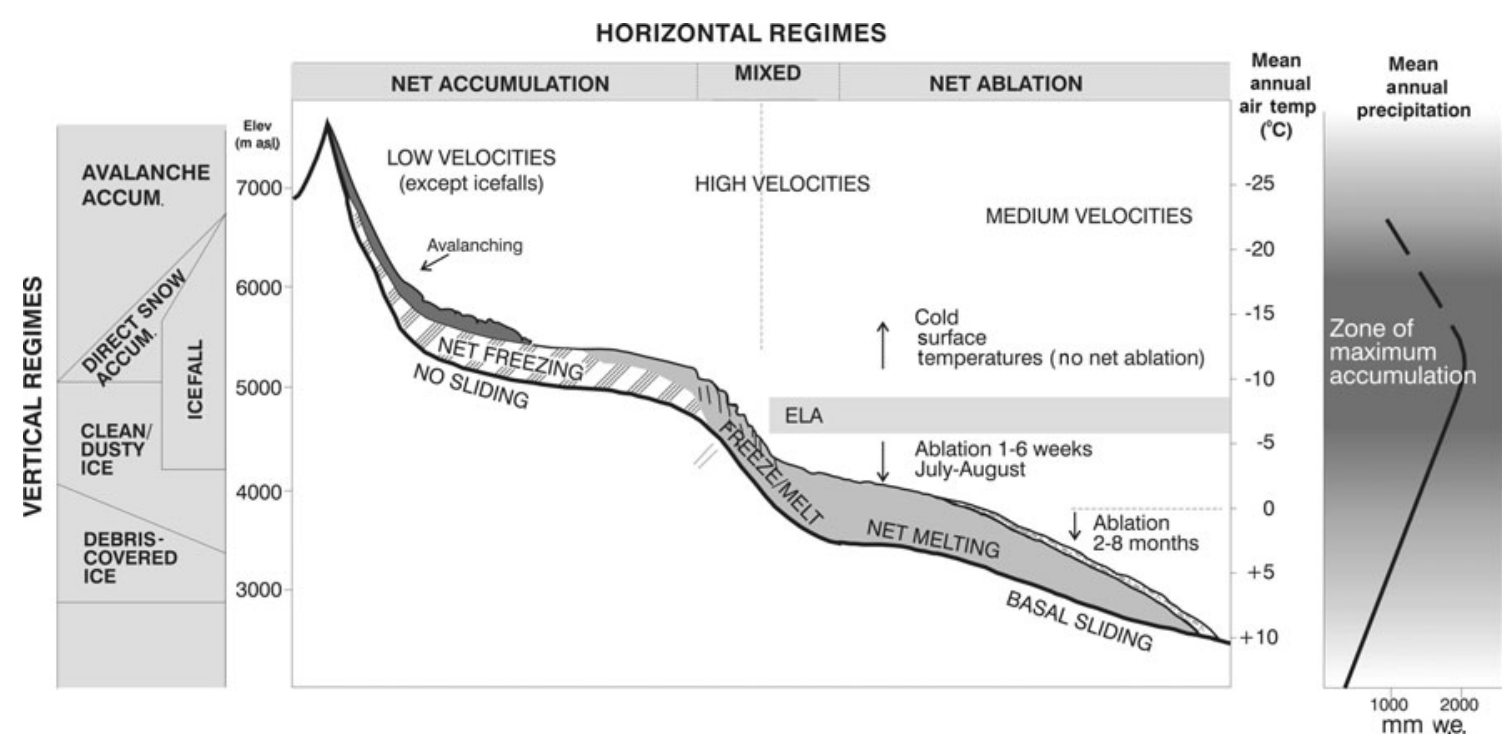

Fig. 8. Area-altitude relations of glacier environments in the central Karakoram identify regime factors that could affect surging or climatic influences on it. The air temperatures shown differ from accumulation zone snow and ice. In open, avalanche-free areas at 5000$6000 \mathrm{~m}$ a.s.I., firn temperatures at depth in pits and cores were at least $5^{\circ} \mathrm{C}$ warmer (Wake, 1989).

reflect the temperature of accumulation zone snow. It may take centuries for the latter to reach and affect the base of the glacier, kilometres away. However, conditions in these steep, avalanche-fed glaciers with large icefalls (Fig. 8) may accelerate response to thermal change (Hewitt, 2005).

Climate change here, as elsewhere, affects variability and not just trends in mean conditions. Eisen and others (2005, p. 404) argue that episodes of exceptional melting and influxes of free water may be the precursors of some surges and of their termination. In the Karakoram, the impact of ablation on glacier behaviour is reflected by a $20-30 \%$ increase in normal summer movement rates compared to winter (Hewitt and others, 1989). Two kinds of anecdotal report from the surge-triggering zones may be relevant. Between 1998 and 2005, the writer has observed midsummer slush flow activity originating above $4000 \mathrm{~m}$ a.s.l., of previously unrecorded scope. Many flows travelled several kilometres, and there was ponding in slush swamps. One of these, near the equilibrium-line altitude on Biafo Glacier in 1999, covered more than $2 \mathrm{~km}^{2}$ and two-thirds the width of the ice. The activity was associated with heavy, late-spring snowfalls, with wet snow, and water ponded or flowing over ice lenses beneath the firn surface as high as $5600 \mathrm{~m}$. Also involved were short-term episodes of exceptional warmth despite, perhaps related to, stormier summer weather. Meanwhile, as in the Qomolangma region, mountaineers report changes in the quality of high-altitude ice and snow towards a 'more tropical' or a 'rotten' consistency. This suggests an increase in high-elevation snow temperatures, at odds with evidence of summer cooling at lower elevations.

Progressive warming of ice over the past century, and/or short-term, intensive melting events in critical areas, have the potential to accelerate or trigger surges. They may preempt the surge cycle and cause a convergence of surges in different glaciers. Perhaps tributaries, the smaller glaciers at high elevations, are especially susceptible. Finally, there are the implications of the sudden and irregular expansions in many non-surging Karakoram glaciers since the mid-1990s (Hewitt, 2005). A shift to positive mass balance may be taking place, in keeping with weather-station records and gauging stations that show reduced run-off from the most heavily glacierized Hunza basin (Archer and Fowler, 2004). Again, however, the suddenness of the changes must be considered and their confinement to the highest watersheds. This suggests thermal and/or hydrological threshold(s) being crossed that trigger downslope redistribution of ice by normal as well as surging flow, with or without massbalance changes.

\section{ACKNOWLEDGEMENTS}

I thank M.J. Hambrey for helpful comments on an early version and I. Evans on Figure 8, two anonymous reviewers for many helpful suggestions and P. Schaus for preparing the figures. Earlier baseline studies drawn on here were funded by the International Development Research Centre, Ottawa, Canada; Pakistan's Water and Power Development Authority; and Wilfrid Laurier University's Office of Research. Mountain guides Mohammed Khan of Hushe, Ghulam Mohammad and Mohammad Ibrahim of Haldi, greatly assisted in the field.

\section{REFERENCES}

Ageta, Y. and K. Fujita. 1996. Characteristics of mass balance of summer-accumulation type glaciers in the Himalayas and Tibetan Plateau. Z. Gletscherkd. Glazialgeol., 32(2), 61-65.

Archer, D.R. and H.J. Fowler. 2004. Spatial and temporal variations in precipitation in the Upper Indus Basin, global teleconnections and hydrological implications. Hydrol. Earth Syst. Sci., $\mathbf{8}(1), 47-61$

Barry, R.G. 1992. Mountain weather and climate. Second edition. London and New York, Routledge.

Batura Glacier Investigation Group. 1979. The Batura Glacier in the Karakoram Mountains and its variations. Sci. Sin., 22(8), 958-974.

Benn, D.I. and D.J.A. Evans. 1998. Glaciers and glaciation. London, Arnold.

Clarke, G.K.C. and E.W. Blake. 1991. Geometric and thermal evolution of a surge-type glacier in its quiescent state: Trapridge Glacier, Yukon Territory, Canada, 1969-89. J. Glaciol., 37(125), 158-169. 
Clarke, T.S. 1991. Glacier dynamics in the Susitna River basin, Alaska, U.S.A. J. Glaciol., 37(125), 97-106.

Dowdeswell, J.A., G.S. Hamilton and J.O. Hagen. 1991. The duration of the active phase on surge-type glaciers: contrasts between Svalbard and other regions. J. Glaciol., 37(127), 388-400.

Eisen, O., W.D. Harrison and C.F. Raymond. 2001. The surges of Variegated Glacier, Alaska, USA, and their connection to climate and mass balance. J. Glaciol., 47(158), 351-358.

Eisen, O., W.D. Harrison, C.F. Raymond, K.A. Echelmeyer, G.A. Bender and V.V. Gordeev. 2005. Variegated Glacier, Alaska, USA: a century of surges. J. Glaciol., 51(174), 399-422.

Fowler, A.C., T. Murray and F.S.L. Ng. 2001. Thermally controlled glacier surging. J. Glaciol., 47(159), 527-538.

Hewitt, K. 1969. Glacier surges in the Karakoram Himalaya (Central Asia). Can. J. Earth Sci., 6(4, Part 2), 1009-1018.

Hewitt, K. 1993. The altitudinal distribution of Karakoram geomorphic processes and depositional environments. In Shroder, J.F., Jr, ed. Himalaya to the sea: geology, geomorphology and the Quaternary. New York, Routledge, 159-183.

Hewitt, K. 1998. Glaciers receive a surge of attention in the Karakoram Himalaya. Eos, 79(8), 104-105.

Hewitt, K. 2005. The Karakoram anomaly? Glacier expansion and the 'elevation effect', Karakoram Himalaya. Mt. Res. Dev., 25(4), 332-340.

Hewitt, K., C.P. Wake, G.J. Young and C. David. 1989. Hydrological investigations at Biafo Glacier, Karakoram Himalaya: an important source of water for the Indus River. Ann. Glaciol., 13. 103-108.

Jiskoot, H., T. Murray and P. Boyle. 2000. Controls on the distribution of surge-type glaciers in Svalbard. J. Glaciol., 46(154), 412-422.

Kamb, B. 1987. Glacier surge mechanism based on linked cavity configuration of the basal water conduit system. J. Geophys. Res., 92(B9), 9083-9100.
Kotlyakov, V.M., ed. 1997. Atlas snezhno-ledovykh resursa mira [World atlas of snow and ice resources]. Moscow, Russian Academy of Sciences. Institute of Geography.

Lawson, W. 1996. Structural evolution of Variegated Glacier, Alaska, U.S.A., since 1948. J. Glaciol., 42(141), 261-270.

Mason, K. 1930. The glaciers of the Karakoram and neighbourhood. Rec. Geol. Surv. India, 63(2), 214-278.

Murray, T., J.A. Dowdeswell, D.J. Drewry and I. Frearson. 1998. Geometric evolution and ice dynamics during a surge of Bakaninbreen, Svalbard. J. Glaciol., 44(147), 263-272.

Oerlemans, J. 2001. Glaciers and climate change. Lisse, etc., A.A. Balkema.

Paterson, W.S.B. 1994. The physics of glaciers. Third edition. Oxford, etc., Elsevier

Pecci, M. and C. Smiraglia. 2000. Advance and retreat phases of the Karakorum glaciers during the 20th century: case studies in Braldo Valley (Pakistan). Geogr. Fís. Din. Quat., 23(1), 73-85.

Sharp, M. 1988. Surging glaciers: behaviour and mechanisms. Progr. Phys. Geogr., 12(3), 349-370.

Spoleto, A. di Savoia-Aosta, duca di and A. Desio. 1936. La spedizione geografica Italiana nel Caracoram, 1929 (storia del Viaggio e resultati geografici). Milan, Arte Grafiche Bertarelli.

von Wissmann, H. and H. Flohn. 1959. Die heutige Vergletscherung und Schneegrenze in Hochasien mit Hinweisen auf die Vergletscherung der letzten Eiszeit. Akad. Wiss. Lit. Mainz Math.-Naturwiss. Kl. Abh., 14, 1103-1431.

Wake, C.P. 1989. Glaciochemical investigations as a tool for determining the spatial and seasonal variation of snow accumulation in the central Karakorum, northern Pakistan. Ann. Glaciol., 13, 279-284.

Wake, C.P. and M.P. Searle. 1993. Correspondence. Rapid advance of Pumarikish Glacier, Hispar Glacier basin, Karakoram Himalaya. J. Glaciol., 39(131), 204-206. 